\title{
Effectiveness of Salty Sand in Improving the Adobe's Thermomechanical Properties: Adrar Case Study (South Algeria)
}

\author{
Abdelkader Bassoud ${ }^{1, *}$, Hamid Khelafi ${ }^{2}$, \\ Abderrahmane Mejedoub Mokhtari ${ }^{1}$ and Abdelmalek Bada ${ }^{1}$ \\ ${ }^{1}$ Laboratoire des Matériaux, Sols et Thermique, Université des Sciences et de la Technologie d'Oran \\ Mohamed Boudiaf USTO-MB, Bir El Djir, Algeria \\ ${ }^{2}$ Laboratory of Sustainable Development and Computer Science, University Ahmed draia of Adrar, \\ Adrar, Algeria
}

('Corresponding author’s e-mail: abdelkader.bassoud@univ-usto.dz)

Received: 25 January 2021, Revised: 20 June 2021, Accepted: 24 June 2021

\begin{abstract}
Adobe constructions have always existed, particularly in the Sahara's dry and scorching regions. This material has a high thermal inertia and can protect buildings from inclement weather. Its mechanical resistance, on the other hand, is still low and has to be increased. The current research, thus, investigated the effect of sand salinity on the thermal and mechanical properties of adobe. The sand needed to create adobe blocks was purchased from 2 distinct locations. The first one was normal sand while the other one was salty sand rich in $\mathrm{SO}_{4}{ }^{-}$sulfate. We considered different ratios of each sand from 10, 20 up to $90 \%$. The results showed that the adobe made from the sulfate-containing sand improved the compressive strength by about $36 \%$ from 1.91 to $2.58 \mathrm{MPa}$, and flexural strength by about $71 \%$, from 0.35 to 0.60 $\mathrm{MPa}$, and reduced the thermal conductivity by $14 \%$ from 0.86 to $0.72 \mathrm{w} / \mathrm{mk}$.
\end{abstract}

Keywords: Adobe, Arid zones, Mechanical resistance, Normal sand, Salty sand, Thermal conductivity

\section{Introduction}

In almost, dry and temperate climates, earth has always been the most common building material $[2,3]$. Today, at least $30 \%$ of the world's population (about 1.5 billion people) live in houses built on earth [4]. We found that the first prefabricated building elements used by humans were molded earth bricks called Adobe. It is a construction material made from a mixture of sand, clay, and water until it reaches a semi-stable paste state, then formed in wooden molds or by hand, and left out in the open air under the sun to dry [2,5-7].

This material has a positive environmental impact, [8] economical [9] fire-resistant; it absorbs pollutants and encourages self-construction[2,5-7], is recyclable [10], and does not consume energy in its manufacture [11]. Adobe brick building walls are considered load-bearing elements. It resists the compression resulting from the weight of the roof. Therefore, compressive strength in adobe buildings is a significant factor. The walls' average compressive strength is about $70 \%$ of the materials' average compressive strength making up the walls [12]. Increased compressive strength of adobe can result in increased overall strength of walls, building improvement, and building longevity. We also recorded a compressive strength value in existing adobe buildings between 0.2 and $2 \mathrm{MPa}$. [13,14].

The subject of improving Adobe's compressive strength has always been of great interest to researchers in various parts of the world. Several research pieces have evaluated the effect of adding various materials, natural or synthetic, on the compressive strength of Adobe, for example. We have reported that $P$. roxburghii and $G$. optiva fibers' addition improved the strength by up to $145-235 \%$ [15]. Similarly, fonio straw (Digitaria exilis) contributed to increase the corrosion resistance of the water and improve the compressive strength [16]. Jové-Sandoval et al. [17] noted that pine needles in adobe paste contributed to increasing its strength up to $24 \%$ compared to straw. Marie Giroudon et al. [18] compared the addition of the 2 straws, lavender and ocean, and showed that the ultimate compressive strength corresponds to $6 \%$ lavender straw, which is higher than $3 \%$ ocean straw. Moreover, the addition of a small percentage of desulfurization waste improved this strength to $7.5 \mathrm{MPa}$. [19]. However, the addition of phosphogypsum and natural gypsum waste increased the compressive strength to $4.72 \mathrm{MPa}$. 
[20]. Furthermore, the addition of barley straw brought it to 5.6 MPa [21]. And also. Lime and cocoa ash with clay increased the compressive strength to $5.85 \mathrm{MPa}$ [22]. Jokhio et al. [23] noted that the Embedded steel wire reinforcement of adobe brick improved its strength by 3 multiples on the contrary. One study concluded that adding more cellulose fibers could reduce the thermal conductivity, compressive and flexural strength of bricks [24]. Similarly, the addition of straw in Adobe reduced bulk density, bearing capacity and modulus of elasticity [25]. Another study concluded a decrease in the compressive strength of adobe; when they incorporate pig hair at $40 \%$ [26].

While the majority of research have used natural or synthetic elements in adobe paste, these components are not readily available in sufficient quantities to fulfill the demands of earthen building. In this study, we study the influence of the $\mathrm{SO}_{4}$ sulfate content in the sand and the sand content in the mixture in the adobe on its compressive and flexural strengths and its thermal characteristics. The objective of this study is the exploitation of abundant saline sand deposits in the desert region to improve the compressive and flexural strengths of adobe bricks.

\section{Methodology}

\section{Study site description}

The province of Adrar is located in southern Algeria. With geographic coordinates $27^{\circ} 52^{\prime} 27^{\prime \prime N}$, and $0^{\circ} 17^{\prime} 37^{\prime \prime} \mathrm{W}$, at an altitude of $257 \mathrm{~m}$ Figure 1. According to De Marton, its climate has been classified as hyper-arid [27,28], with a stifling summer and a very cold winter. This region includes many saline sites and a large sand reserve. The houses have been built in adobe for centuries.
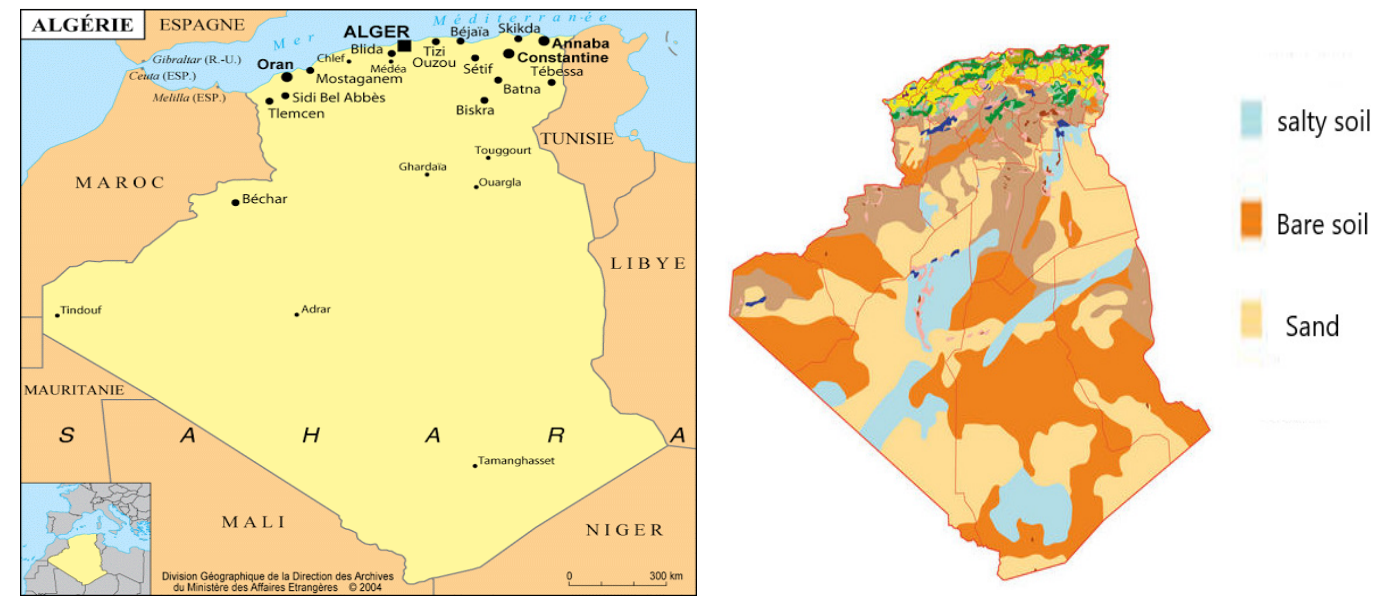

Figure 1 Position of study sites [1].

\section{Materials used \\ Sand}

We have chosen 2 sand resources to carry out this comparative study: One normal sand and the other salty sand, taken from the same region.

The sands previously came from the region of Bouda, in the Wilaya (province) of Adrar, with geographic coordinates $28^{\circ} 0^{\prime} 38.95^{\prime \prime} \mathrm{N}, 0^{\circ} 25^{\prime} 32.95^{\prime \prime} \mathrm{W}$ for the normal sand. And $28^{\circ} 0^{\prime} 14.89^{\prime \prime} \mathrm{N}$ and $0^{\circ} 26^{\prime} 20.81^{\prime \prime} \mathrm{W}$ for the salty sand. We measured the physico-chemical analyses in the LTPO laboratory in Oran.

Table 1 summarizes the results of the different physical properties obtained according to the standards NF. EN 933-8, NF. P94-057 [29,30], we can conclude that the 2 grains of sand, normal, and salty are very clean with an almost total absence of fine clay particles. 
Table 1 The physical characteristics of sands.

\begin{tabular}{lcc}
\hline Physical properties & Salty sand & Normal sand \\
\hline Wet density & $1.58 \mathrm{t} / \mathrm{m}^{3}$ & $1.58 \mathrm{t} / \mathrm{m}^{3}$ \\
Density & $2.741 \mathrm{t} / \mathrm{m}^{3}$ & $2.61 \mathrm{t} / \mathrm{m}^{3}$ \\
Fineness modulus & 2.31 & 2.31 \\
Sand equivalent & $83 \%$ & $87 \%$ \\
\hline
\end{tabular}

Table 2 presents the results of the various mineralogical properties obtained. These results show a high content of $\mathrm{SO}_{4}$ sulphate salt in the salty sand compared to normal sand, This presents an environment with high chemical aggressiveness $\left(\mathrm{SO}_{4}>12000\right.$, class XA3), NF EN 206-1 [29-32].

Table 2 The mineralogical characteristics of sands.

\begin{tabular}{lccccccc}
\hline \multicolumn{7}{c}{ Content (\%) } \\
\hline Component & $\mathrm{SiO}_{3}$ & $\mathrm{CaO}$ & $\mathrm{Al}_{2} \mathrm{O}_{3}$ & $\mathrm{FeO}_{3}$ & $\mathrm{SO}_{4}(\mathrm{mg} / \mathrm{kg})$ & $\mathrm{CaCO}_{3}$ & $\mathrm{CO}_{2}$ \\
Normal sand & 89.10 & 6.20 & $\mathrm{Nul}$ & 1.39 & 3087.00 & 4.67 & 2.05 \\
Salty sand & 78.50 & 3.59 & 0.37 & 1.16 & 17493.00 & 9.34 & 4.11 \\
\hline
\end{tabular}
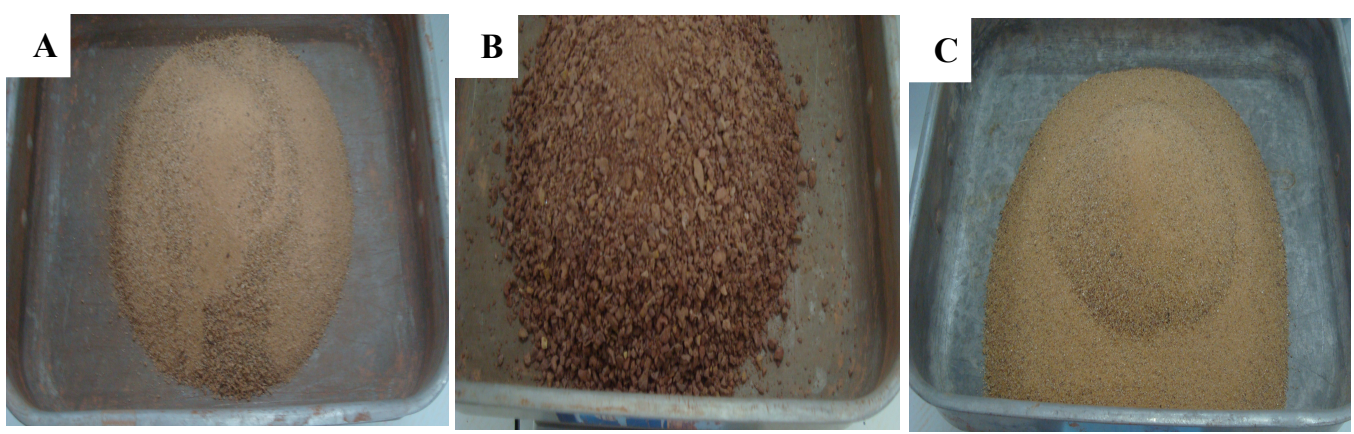

Figure 2 A) salty sand, B) clay and C) normal sand.

\section{Clay}

The clay used; also comes from the region of Adrar (Bouda), with geographical coordinates $27^{\circ} 54^{\prime} 56.66^{\prime \prime} \mathrm{N}$ and $0^{\circ} 16^{\prime} 40.40^{\prime \prime} \mathrm{W}$. We carried out analyses in the LTPOran's laboratory. The results obtained are in the following tables.

Table 3 The physical characteristics of the clay used.

\begin{tabular}{ll}
\hline \multicolumn{1}{c}{ Characteristics } & Results \\
\hline Apparent density & $2.64 \mathrm{~g} / \mathrm{cm}^{3}$ \\
Methylene blue (NF 933-9)[33] & VBS $=9.5$ \\
Atterberg limits (NF P94-051)[34] & \\
IP & $38.86 \%$ \\
W1 & $64.46 \%$ \\
wp & $25.60 \%$ \\
\hline
\end{tabular}


The test of methylene blue is made according to the standard NFP 933-9, it consists in controlling the absorption of the injected methylene blue, if the VBS $>8$, the soil is classified between argillaceous and very argillaceous, after determination of the Index of plasticity Ip and according to NF P94-051. Suppose Ip $<40$; the clay is classified as plastic.

Table 4 The Mineral composition of clay from the area of Adrar.

\begin{tabular}{cccccccc}
\hline \multicolumn{7}{c}{ Content (\%) } \\
\hline Component & $\mathrm{SiO}_{3}$ & $\mathrm{CaO}$ & $\mathrm{Al}_{2} \mathrm{O}_{3}$ & $\mathrm{FeO}_{3}$ & $\mathrm{SO}_{4}(\mathrm{mg} / \mathrm{kg})$ & $\mathrm{CaCO}_{3}$ & $\mathrm{CO}_{2}$ \\
& 82.10 & 1.96 & 3.33 & 4.41 & 13720.00 & 0.93 & 0.41 \\
\hline
\end{tabular}

The clay has been evaluated according to its chemical constituents; the principal oxides checked are $\mathrm{SiO}_{2}, \mathrm{Al}_{2} \mathrm{O}_{3}$ and $\mathrm{Fe}_{2} \mathrm{O}_{3}$, the amount of $\mathrm{CO}_{3}$ and $\mathrm{CaCO}_{3}$ is low.

From an industrial point of view, the ratio $\mathrm{Al}_{2} \mathrm{O}_{3} / \mathrm{FeO}_{3}$ is less than 5.5, which means that this clay is rich in iron and can be used in the manufacture of building materials (bricks, tiles, ... etc.) [35].

\section{Mixing water}

The water used comes from the drinking water distribution system of the city of Adrar. The chemical analyses were done in the laboratory of the ANRH of the city of Adrar. Table 5 shows the chemical analyses of the water used in the adobe mixture. According to the directives of the World Health Organization [36] concerning the potability of water, the $\mathrm{pH}$ of the water must be between 6.5 and 9 and the content of sulfate $\mathrm{SO}_{4}{ }^{-}$must be less than $250 \mathrm{mg} / \mathrm{L}$, chlorides $\mathrm{Cl}^{-}$must be less than $200 \mathrm{mg} / \mathrm{L}$ and potassium $\mathrm{K}^{+}$must be less than $12 \mathrm{mg} / \mathrm{L}$ and magnesium $\mathrm{Mg}^{+}$less than $150 \mathrm{mg} / \mathrm{L}$. All the results of the analyses obtained, chemical, organoleptic, microbiological, and the parameters related to undesirable substances, related to toxic substances, show that this water is potable.

Table 5 The mineral composition of Adrar's drinking water.

\begin{tabular}{ccccccccc}
\hline \multicolumn{10}{c}{ Composition } \\
\hline & $\mathrm{pH}$ & $\mathrm{Rs}$ & $\mathrm{Ca}^{+}$ & $\mathrm{Mg}^{+}$ & $\mathrm{Na}^{+}$ & $\mathrm{K}^{+}$ & $\mathrm{Cl}^{-}$ & $\mathrm{SO}_{4}^{-}$ \\
& 7.51 & 640 & 51 & 38 & 100 & 7 & 140 & 210 \\
$\begin{array}{c}\text { Concentration } \\
\mathbf{m g} / \mathbf{L}\end{array}$ & $\mathrm{NO}_{3}^{-}$ & $\mathrm{HCO}_{3}^{-}$ & $\mathrm{NH}_{4}^{+}$ & $\mathrm{NO}_{2}^{-}$ & $\mathrm{PO}_{4}^{-}$ & $\mathrm{MO}$ & $\mathrm{SI}$ & \\
& 19.144 & 119 & 0.007 & 0.01 & 0 & 1.4 & 684 & \\
\hline
\end{tabular}

\section{Samples}

We prepared several adobe specimens using different sand and clay percentages to study the influence of sand and clay ratios on thermo-mechanical properties. Mixtures in Table 6 presented 18 variants of adobe samples with various sand percentages (normal/salty) and clay. We counted a total of 90 pieces. The setting occurred in the open air. 
Table 6 The compositions of the studied samples.

\begin{tabular}{cccccc}
\hline $\begin{array}{c}\text { The } \\
\text { Composition }\end{array}$ & sample & Percentages & Composition & sample & Percentages \\
\hline & $\mathrm{C}_{\mathrm{d}} 1$ & $10 \%$ clay $+90 \%$ Normal sand & & $\mathrm{Cs} 1$ & $10 \%$ clay $+90 \%$ Salty sand \\
& $\mathrm{C}_{\mathrm{d}} 2$ & $20 \%$ clay $+80 \%$ Normal sand & & $\mathrm{Cs} 2$ & $20 \%$ clay $+80 \%$ Salty sand \\
& $\mathrm{C}_{\mathrm{d}} 3$ & $30 \%$ clay $+70 \%$ Normal sand & & $\mathrm{Cs} 3$ & $30 \%$ clay $+70 \%$ Salty sand \\
Normal Sand & $\mathrm{C}_{\mathrm{d}} 4$ & $40 \%$ clay $+60 \%$ Normal sand & Salty sand & $\mathrm{Cs} 4$ & $40 \%$ clay $+60 \%$ Salty sand \\
& $\mathrm{C}_{\mathrm{d}} 5$ & $50 \%$ clay $+50 \%$ Normal sand & & $\mathrm{Cs} 5$ & $50 \%$ clay $+50 \%$ Salty sand \\
& $\mathrm{C}_{\mathrm{d}} 6$ & $60 \%$ clay $+40 \%$ Normal sand & & $\mathrm{Cs} 6$ & $60 \%$ clay $+40 \%$ Salty sand \\
& $\mathrm{C}_{\mathrm{d}} 7$ & $70 \%$ clay $+30 \%$ Normal sand & & $\mathrm{Cs} 7$ & $70 \%$ clay $+30 \%$ Salty sand \\
& $\mathrm{C}_{\mathrm{d}} 8$ & $80 \%$ clay $+20 \%$ Normal sand & $\mathrm{Cs} 8$ & $80 \%$ clay $+20 \%$ Salty sand \\
& $\mathrm{C}_{\mathrm{d}} 9$ & $90 \%$ clay $+10 \%$ Normal sand & Cs 9 & $90 \%$ clay $+10 \%$ Salty sand \\
\hline
\end{tabular}

Figure 3 shows 2 images of adobe under a scanning electron microscope; the first image is of an adobe made of normal sand and the second of an adobe made of salty sand. When we mix clay with sand and water, we notice that the normal sand retains the granules with a high adobe percentage. Contrary to the salty sand, the ratio of sand grains in the adobe is slightly low. As salts surround the salty sand grains, most of them dissolve when mixed with water.
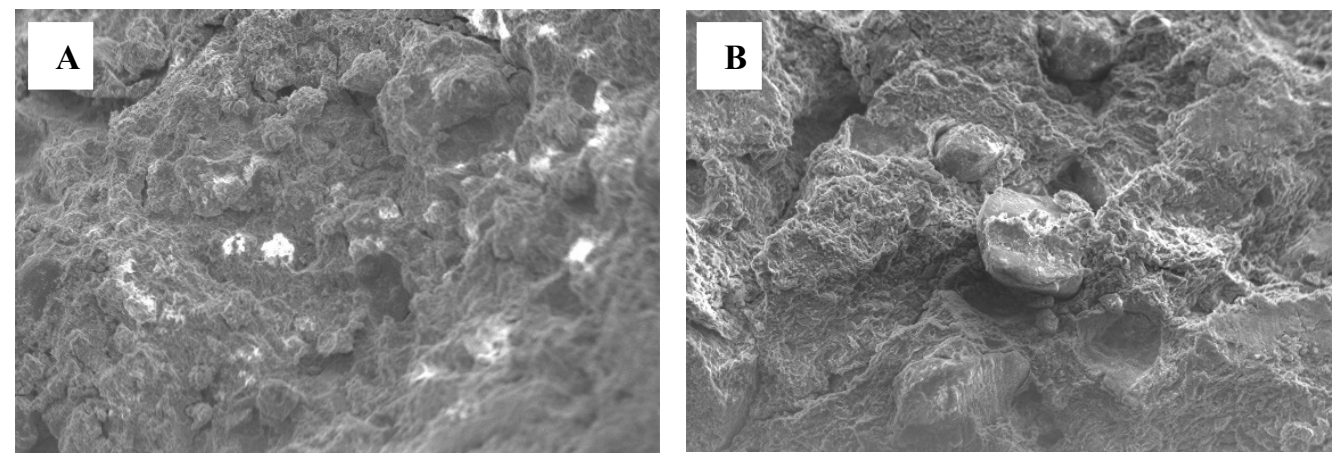

Figure 3 Images according to SEM; A) adobe with salty sand, B) adobe with normal sand.

\section{Mechanical and thermal testing}

The uniaxial compression test was performed on simple cylindrical loads at a constant speed until the test piece broke Figure 4A This test aims to determine the compressive strength of the sample (NBNB24.201). Samples used are cylindrical; their height is $10 \mathrm{~cm}$, and their diameter $5 \mathrm{~cm}$. The following formula gives the compressive stress of the specimen;

$$
f_{C}=\frac{p}{A}
$$

$f_{c}$ is the compressive strength $\left(\mathrm{N} / \mathrm{cm}^{2}\right), P$ is the maximum load supported by the specimen, and $A$ is the average gross cross-sectional area.

According to the European standard EN1015-11 [37], the flexural strength is determined by applying a concentrated load on a specimen in the middle of the distance between the 2 supports (Figure 4B). In the laboratory of the University of Becher, we tested the specimens of dimensions $40 \times 40 \times 160$ $\mathrm{mm}^{3}$, and the flexural strength is determined according to the following equation;

$$
R_{f}=1,5 \frac{F l}{b d^{2}}
$$

$R_{f}$ is the flexural strength $\left(\mathrm{N} / \mathrm{mm}^{2}\right)$, 
$F$ is the maximum load applied to the middle of the prism $(\mathrm{N})$,

$l$ is the distance between the 2 supports $(\mathrm{mm})$,

$b$ is the average width of the specimen in $(\mathrm{mm})$,

$d$ is the average length of the specimen in ( $\mathrm{mm})$.

We measured thermal characterization tests on specimens of dimensions $100 \times 100 \times 50 \mathrm{~mm}^{3}$ in the ENPOran laboratory, Figure 4 using the ISOMET 2104 equipment [38].
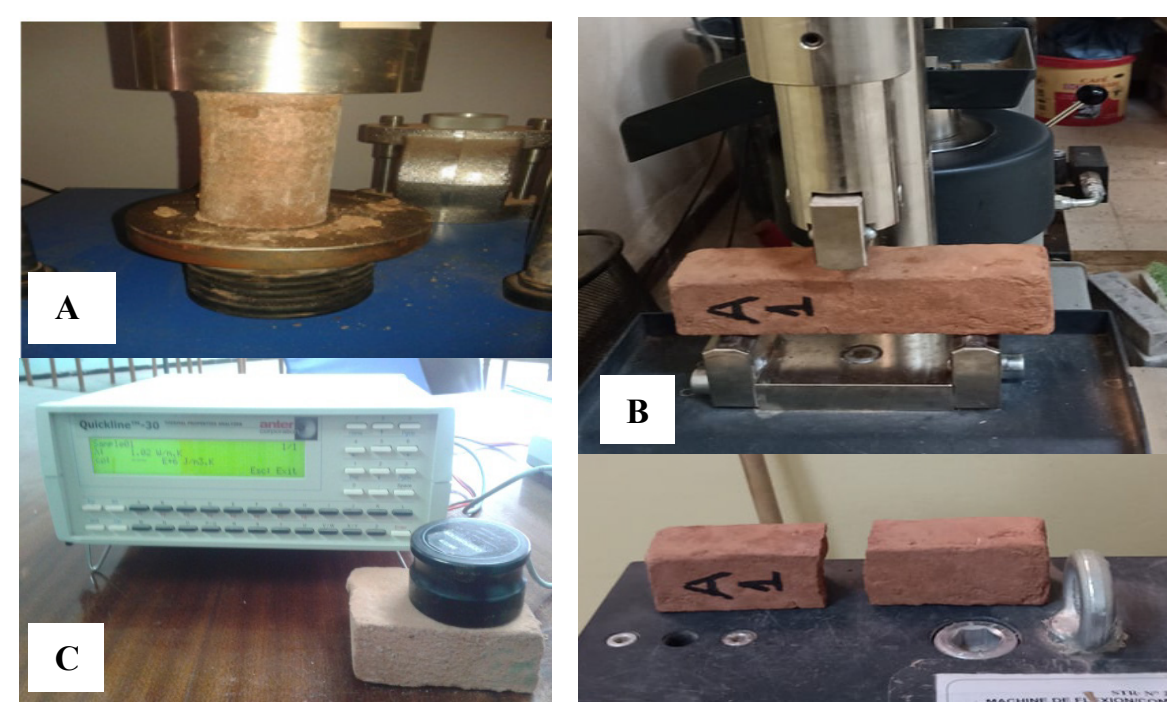

Figure 4 Tests; A) crushing of samples, B) 3-point flexural test and C) measurement of thermophysical characteristics with ISOMET 2104.

\section{Results and discussion}

\section{Compressive strength}

Figure 5 shows the variation of compressive strength of the samples with the percentage of sand in each mixture; for 2 types of sand. The compressive strength of the adobe prepared with normal sand with 20, 30 and $40 \%$ increased from 1.65 to $1.78,1.82$ and $1.90 \mathrm{MPa}$, respectively, which presents improvement rates of 6, 10 and $11 \%$, respectively. However, the mixtures with 60, 70, 80 and $90 \%$ sand contents experienced a decrease in compressive strength from 1.91 to $1.82,1.78$ and $1.45 \mathrm{MPa}$, respectively, which corresponds to 7, 14, 21 and $31 \%$ compared to the mixture with $50 \%$ normal sand. The highest compressive strength value corresponds to the mixture of $50 \%$ sand and $50 \%$ clay, where its strength reached $1.92 \mathrm{MPa}$. For the adobe prepared with salty sand, the 20,30 and $40 \%$ mixtures showed an improvement in strength, from 2.18 to $2.2,2.28$ and $2.49 \mathrm{MPa}$ with ratios of 3,14 and $18 \%$, respectively. However, the strength decreased significantly for the 60,70 and $80 \%$ sand mixtures, from 2.58 to $2.38,2.23$ and $1.91 \mathrm{MPa}$ with ratios of 14,26 and $34 \%$, respectively. Note that $2.58 \mathrm{MPa}$ corresponds to the compressive strength of the adobe obtained from the $50 \%$ salt sand $+50 \%$ clay mixture.

Comparing the 2 curves of compressive strength, we noted that the salty sand improves the compressive strength of 24, 36 and $30 \%$ for the mixtures of 10,40 and $80 \%$ compared to the normal sand. Therefore, the optimum mix for compressive strength was $50 \%$ sand $+50 \%$ clay for both types of sand. However, increasing the percentage of sand beyond $50 \%$ reduces the compressive strength of the adobe. 


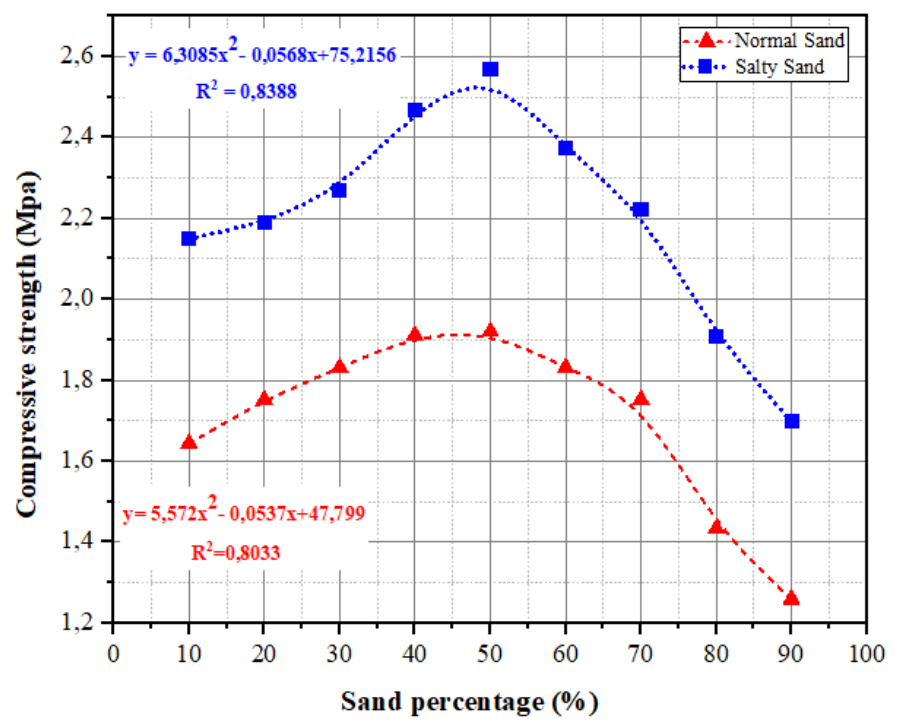

Figure 5 Compressive strength as a function of sand content.

\section{Flexural strength}

Figure 6 shows the variation of flexural strength as a function of sand ratios in the adobe mixture in the 2 cases of sand nature; normal and sulfated saline. In the case of normal sand, the flexural strength is semi-stable for the 20,30 and $40 \%$ ratio mixes ranging from 0.33 to $0.35,0.35$ and $0.37 \mathrm{MPa}$, respectively, the maximum value was reached at 0.36 , which corresponds to the $40 \%$ sand and $60 \%$ clay mix. We then recorded a drop in flexural strength to $0.30,0.25,0.09$ and $0.03 \mathrm{MPa}$ for the $60,70,80$ and $90 \%$ sand content, respectively. It was found that the sand content negatively affects the flexural strength.

For the case of salty sand, we recorded a slight increase in flexural strength at $0.55,0.56,0.58 \mathrm{MPa}$ for the mixtures of 20,30 and $40 \%$, respectively, it was reached for a maximum of $0.6 \mathrm{MPa}$ for the mixture of $50 \%$ sand and $50 \%$ clay, then the flexural strength decreased to $0.5,0.4,0.25$ and to 0.11 $\mathrm{MPa}$ for the mixtures of $60,70,80$ and $90 \%$ of salty sand, respectively. We noticed that the higher the clay content; the flexural strength is stable and higher than the lowest value of $0.35 \mathrm{MPa}$ required by the New Mexico State Earth Building Materials Code.

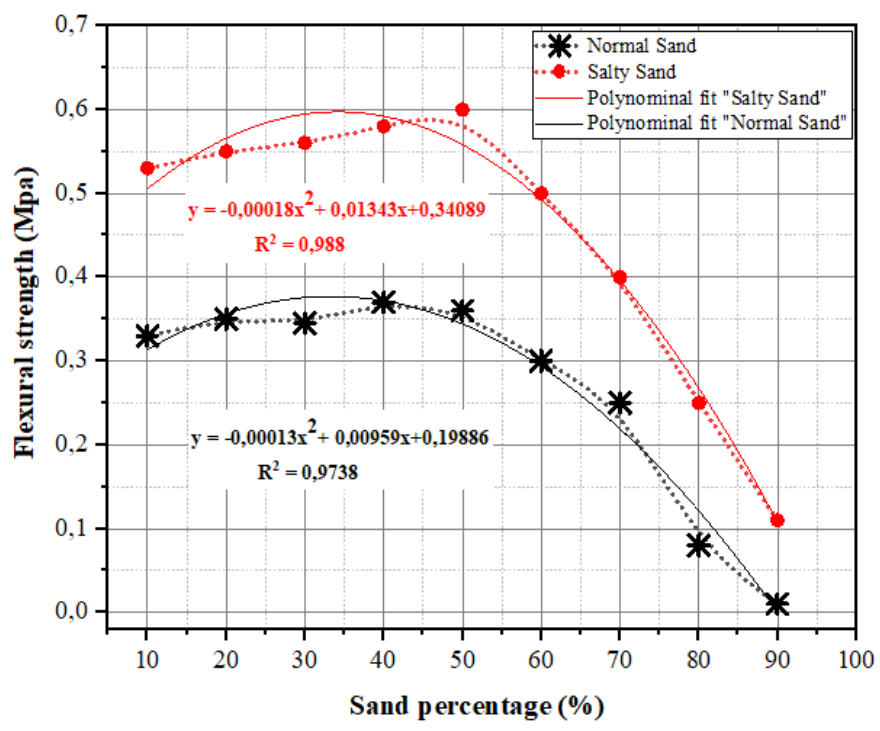

Figure 6 Flexural strength as a function of sand content. 


\section{Thermo-physical characteristics}

The variation of the thermal conductivity of adobe as a function of the percentage and nature of the sand is shown in Figure 7. The thermal conductivity of adobe made from normal sand is almost stable at 15 and $25 \%$; this mixture has a value of $0.72 \mathrm{~W} / \mathrm{mk}$. Then, the thermal conductivity value increases to $0.73,0.75,0.95$ and $1.05 \mathrm{~W} / \mathrm{mk}$ for mixtures with $50,60,70$ and $80 \%$ sand content, respectively. The highest thermal conductivity value equals $1.13 \mathrm{~W} / \mathrm{mk}$, corresponding to the mixture containing $90 \%$ of normal sand. As for the adobe/salty sand mixture, we recorded a low thermal conductivity equal to 0.7 $\mathrm{W} / \mathrm{mk}$ for 10 and $20 \%$ sand contents. This thermal conductivity increases to $0.93,1.0$ and $1.08 \mathrm{~W} / \mathrm{mk}$ for sand proportions at 60,70 and $80 \%$, respectively. The highest thermal conductivity value is $1.1 \mathrm{~W} / \mathrm{mk}$, corresponding to the $90 \%$ sand $+10 \%$ clay mixture.

Based on these results, we noticed that the salty sand reduces the thermal conductivity of the adobe in a ratio between 3 and $14 \%$. The proportion of clay in the adobe also contributed to the low thermal conductivity, and on the contrary, the proportion of sand increased the thermal conductivity.

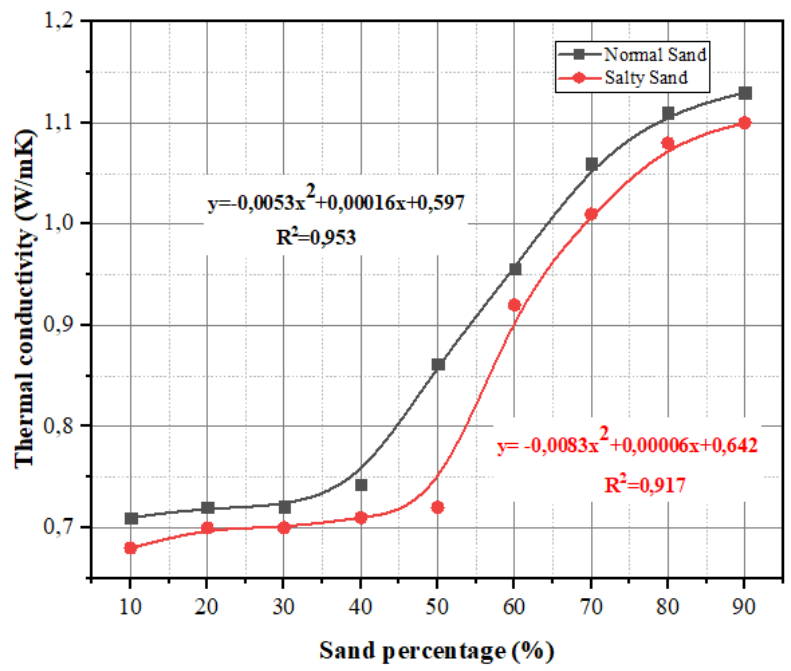

Figure 7 Thermal conductivity of adobe as a function of the sand percentage.

Figure 8 shows the evolution of the specific heat of the adobe as a function of the percentage and nature of the sand. A slight increase does not exceed $3 \%$ for samples with 10, 20, 30 and $40 \%$ of normal sand. Increases, for samples with 60,70 and $80 \%$ of normal sand, to 1500,1548 and $1675 \mathrm{~kJ} / \mathrm{m} 3 \mathrm{~K}$, respectively. The extreme specific heat is $1680 \mathrm{~kJ} / \mathrm{m}^{3} \mathrm{~K}$, corresponding to the mixture of $90 \%$ normal sand $+10 \%$ clay.

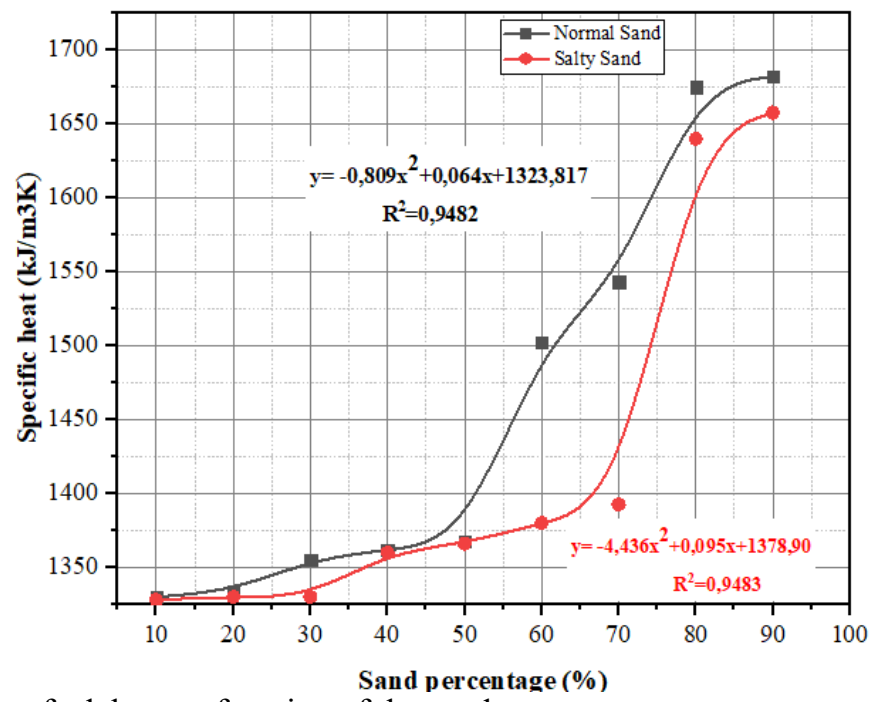

Figure 8 Specific heat of adobe as a function of the sand percentage. 
For adobe made with salty sand, the specific heat increased slightly for mixtures of 10 to $50 \%$, in a ratio not exceeding $4 \%$. However, it increased progressively as the percentage of clay in the mixtures decreased. As a result, we recorded an improvement of 12 and $24 \%$ for the 2 mixtures with 60 and $70 \%$ sand at 1376 and $1390 \mathrm{~kJ} / \mathrm{m}^{3} \mathrm{~K}$, respectively. The highest specific heat is $1652 \mathrm{~kJ} / \mathrm{m}^{3} \mathrm{~K}$, which corresponds to the $90 \%$ sand $+10 \%$ clay mixture.

Comparing the 2 curves in Figure 7, we found that salty sand reduces the specific heat by 2 to $8 \%$ and that the high content of salty sand in adobe bricks decreases the thermal inertia.

\section{Comparison with previous studies}

Table 7 presents a comparison of different studies and treatments carried out on adobe to improve its compressive, flexural strength and the effect of these treatments on its thermal properties.

Table 7 Comparison with previous studies

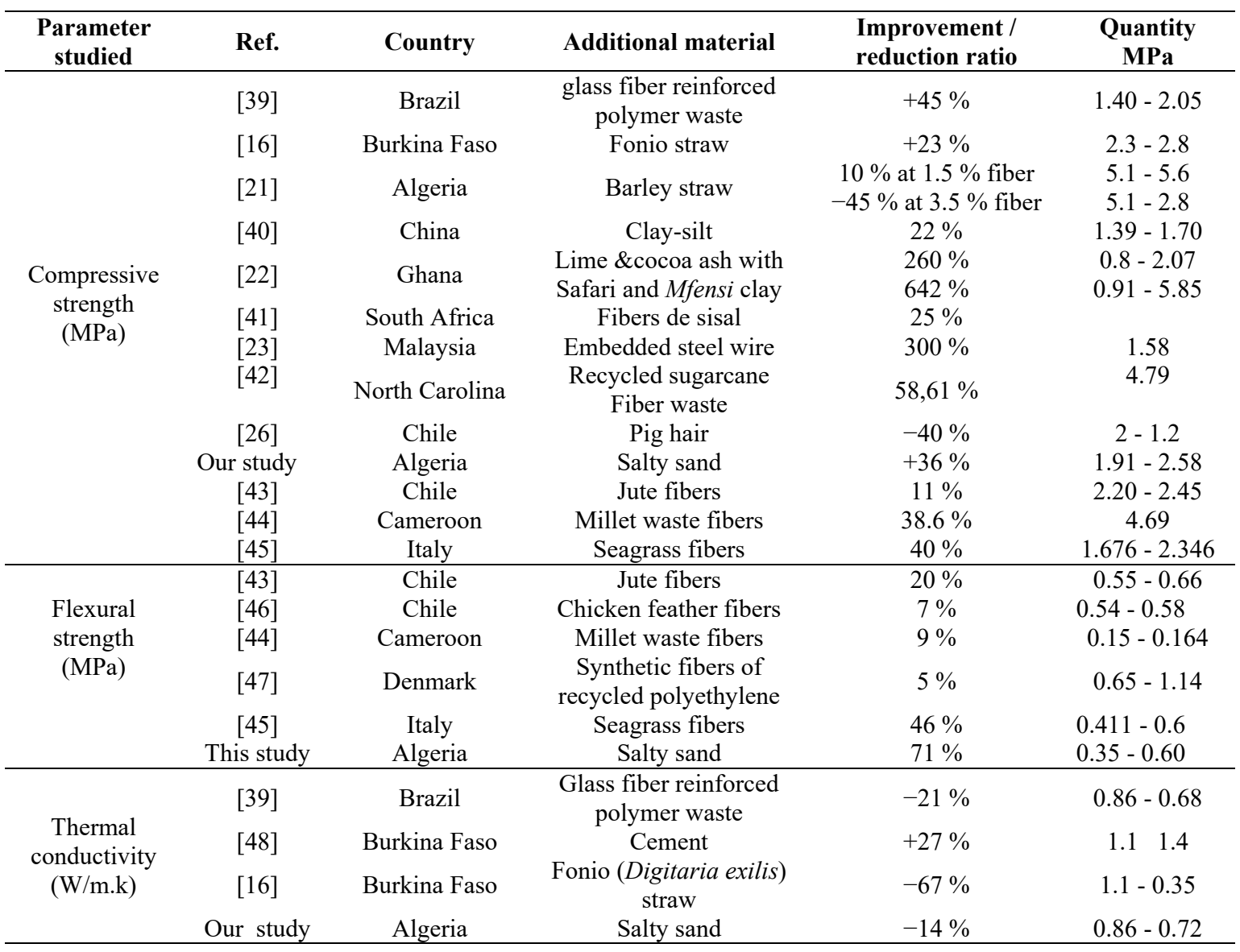

In comparing the different adobe treatments carried out in previous studies, using different additives, natural and synthetic; We have found that most of them have contributed to increasing the compressive strength in variable proportions, from 6 to 3 times, [22,23] or with ratios from 10 to $45 \%$ [16,39-41,43-45]. We have also noted that the additive's percentage merit careful study, and the increase in the percentage of additives up to a specific limit may decrease the adobe strength [21]. Similarly, flexural strength increases by $10 \%$ with the addition of fibers [44,46,47]. It exceeds $46 \%$ in the case of seagrass fibers. We recorded a rate of $71 \%$ with the presence of sulphate. Most studies have shown that the flexural strength only increased at the optimum content of the additions, after which the flexural strength decreased again when the fiber content increased further [49]. Moreover, we found that cement to the adobe increased the thermal conductivity by a significant percentage. Witch contrasts with the various additives decreasing the value of thermal conductivity, improving the efficiency of adobe to insulate houses, especially in hot and dry regions; where adobe is the ideal solution to protect the indoor environment from the aggressiveness of the outdoor climate. 
The proportions obtained in our study of adobe with salty sand are encouraging rates, improvement in compressive strength, and increased thermal insulation value.

\section{Conclusions}

In this study, we studied different adobe types and combined clay and sand in a desert area. Building materials are supposed to be insulating and must adapt quickly to exceptional climatic conditions. They must also provide good mechanical strength to obtain durable constructions. We proved that: The nature of the sand used is fundamental in this respect. Moreover, the salinity of the sand significantly improves its mechanical properties without having any effect on its thermal behaviors and inertia. We have shown that the salty sand used in the making of adobe is very useful and helps to improve its compressive strength from 1.9 to $2.58 \mathrm{MPa}$ with a rate of improvement of $36 \%$. Similarly, the flexural strength increases from 0.35 to $0.60 \mathrm{MPa}$ for a rate of $71 \%$. The adobe has good thermal inertia, and the sulfated salinity of the sand reduces its thermal conductivity by about $14 \%$. The adobe's high specific heat is critical for retarding the outdoor climate's influence on the building. Using salty sand in adobe, we have not recorded any significant negative impact on this thermal property. The use of salty sand as a substitute for normal sand has no economic cost because salty deposits are abundantly available in desert areas, as are normal sand. All these results recommend using adobe made from salt sand as a building material for new buildings. It is also very encouraging to use it as a material for restoring old adobe buildings known locally as Ksar.

\section{Acknowledgements}

The authors are pleased to express their sincere thanks to the Thematic Agency for Research in Science and Technology ATRST for their funding, and to present their gratitude for the voluntary assistance of LSTGP USTOran laboratory members, to all LTPO Oran laboratory engineers.

\section{References}

[1] Map Algerie, Available at: https://fr.maps-algeria.com, accessed December 2020.

[2] G Minke. Building with Earth: Design and technology of a sustainable architecture. $4^{\text {th }}$ ed. Birkhäuser, Basel, Switzerland, 2021.

[3] H Houben and H Guillaud. CRATerre - Traité de construction en terre. Éditions parenthèses, Marseille, France, 2006.

[4] L Keefe. Earth building: Methods and materials, repair and conservation. Taylor \& Francis, London, 2012, p.7.

[5] S Maini. Earthen architecture for sustainable habitat and compressed stabilised earth blocktechnology. Auroville Earth Institute, Tamil Nadu, India, 2005.

[6] EA Adam and ARA Agib. Compressed stabilised earth block manufacture in Sudan. United Nations Educational, Scientific and Cultural Organization, Paris, France, 2001.

[7] K Hadjri, M Osmani, B Baiche and C Chifunda. Attitudes towards earth building for Zambian housing provision. In: Proceedings of the Institution of Civil Engineers: Engineering Sustainability. 2007.

[8] APO Obafemi and S Kurt. Environmental impacts of adobe as a building material: The north cyprus traditional building case. Case Stud. Constr. Mater. 2016; 4, 32-41.

[9] MS Zami and A Lee. Economic benefits of contemporary earth construction in low-cost urban housing-State-of-the-art review. J. Build. App. 2010; 5, 259-71.

[10] G Calatan, A Hegyi, C Dico and C Mircea. Experimental research on the recyclability of the clay material used in the fabrication of adobe bricks type masonry units. Proc. Eng. 2017; 181, 363-9.

[11] A Shukla, GN Tiwari and MS Sodha. Embodied energy analysis of adobe house. Renew. Energ. 2009; 34, 755-61.

[12] J Carvalho, D Silveira, H Varum and A Costa. Mechanical properties and behavior of traditional adobe wall panels of the Aveiro district. American Society of Civil Engineers. 2015; 27, 04014253.

[13] F Fratini, E Pecchioni, L Rovero and U Tonietti. The earth in the architecture of the historical centre of Lamezia Terme (Italy): Characterization for restoration. Appl. Clay Sci. 2011; 53, 509-16.

[14] D Silveira, H Varum, A Costa, T Martins, H Pereira and J Almeida. Mechanical properties of adobe bricks in ancient constructions. Constr. Build. Mater. 2012; 28, 36-44.

[15] V Sharma, HK Vinayak and BM Marwaha. Enhancing sustainability of rural adobe houses of hills by addition of vernacular fiber reinforcement. Int. J. Sustain. Built Environ. 2015; 4, 348-58. 
[16] M Ouedraogo, K Dao, Y Millogo, JE Aubert, A Messan, M Seynou, L Zerbo and M Gomina. Physical, thermal and mechanical properties of adobes stabilized with fonio (Digitaria exilis) straw. J. Build. Eng. 2019; 23, 250-8.

[17] F Jové-Sandoval, MM Barbero-Barrera, NF Medina. Assessment of the mechanical performance of three varieties of pine needles as natural reinforcement of adobe. Constr. Build. Mater. 2018; 187, 205-13.

[18] M Giroudon, A Laborel-Préneron JE Aubert and C Magniont. Comparison of barley and lavender straws as bioaggregates in earth bricks. Constr. Build. Mater. 2019; 202, 254-65.

[19] XW Jia, YJ Zhang and JS Qian. The properties of modified adobe materials with desulfurization waste. Adv. Mater. Res. 2012; 562-564, 47-51.

[20] N Degirmenci. The using of waste phosphogypsum and natural gypsum in adobe stabilization. Constr. Build. Mater. 2008; 22, 1220-4.

[21] M Bouhicha, F Aouissi and S Kenai. Performance of composite soil reinforced with barley straw. Cement Concr. Compos. 2005; 27, 617-21.

[22] R Amoanyi, PS Kwawukume, FWY Momade. Improving the Strength properties of Afari and Mfensi clays by chemical stabilization. Int. J. Eng. Res. Afr. 2012; 8, 1-15.

[23] GA Jokhio, FM Saad, Y Gul, SMS Mohsin and NI Ramli. Uniaxial compression and tensile splitting tests on adobe with embedded steel wire reinforcement. Constr. Build. Mater. 2018; 176, 383-93.

[24] W Namboonruang and P Yongam-Nuai. Thermal, strength and leachability characteristics of cellulose fibre reinforced lime-soil brick. Key Eng. Mater. 2016; 703, 386-95.

[25] R Illampas, VG Loizou and I Ioannou. Effect of straw fiber reinforcement on the mechanical properties of Adobe bricks. In: Proceedings of the $6^{\text {th }}$ Biot Conference on Poromechanics, Paris, France. 2017, p. 1331-8.

[26] G Araya-Letelier, J Concha-Riedel, FC Antico, C Valdés and G Cáceres. Influence of natural fiber dosage and length on adobe mixes damage-mechanical behavior. Constr. Build. Mater. 2018; 174, 645-55.

[27] G Guyot. Climatologie de l'environnement. Dunod, Paris, France, 1999.

[28] MR Yaiche and A Bouhanik. Atlas solaire algérien. Vol. 16. Centre de Développement des Energies Renouvelables, Bouzareah, Algeria, 2002.

[29] Association Francaise de Normalisation. NF P94-057. Sols: Reconnaissance et essais - analyse granulométrique des sols - méthode par sédimentation (in French). Association Francaise de Normalisation, Paris, France, 1992.

[30] Association Francaise de Normalisation. NF EN 933-8. Essais pour déterminer les caractéristiques géométriques des granulats - Partie 8 (in French). Association Francaise de Normalisation, Paris, France, 2015.

[31] Association Francaise de Normalisation. NF EN 206-1. Béton-Partie 1: Spécification, performances, production et conformité (in French). Association Francaise de Normalisation, Paris, France, 2004.

[32] Association Francaise de Normalisation. FD P18-011. Béton - Définifion et classification des environnements chimiquement agressifs - Recommandations pour la formulation des bétons (in French). Association Francaise de Normalisation, Paris, France, 2016.

[33] Association Francaise de Normalisation. NF EN 933-9+A1. Essais pour déterminer les caractéristiques géométriques des granulats - Partie 9 (in French). Association Francaise de Normalisation, Paris, France, 2013.

[34] Association Francaise de Normalisation. NF P94-051. Sols: reconnaissance et essais-Détermination des limites d'Atterberg-Limite de liquidité à la coupelle-Limite de plasticité au rouleau (in French). Association Francaise de Normalisation, Paris, France, 1993.

[35] M Garcia-Valles, P Alfonso, S Martínez and N Roca. Mineralogical and thermal characterization of kaolinitic clays from Terra Alta (Catalonia, Spain). Minerals 2020; 10, 142.

[36] Organisation Mondiale de la Sante. Directives de qualité pour l'eau de boisson (in French). Vol I. Organisation Mondiale de la Sante, Genève, Switzerland, 2004.

[37] European Committee for Standardization. EN 1015-10. Methods of test for mortar for masonry Part 11: Determination of flexural and compressive strength of hardened mortar. European Committee for Standardization, Brussels, Belgium 1999.

[38] Applied Precision. ISOMET model 2104. Bratislava. 
[39] RM Gandia, FC Gomes, AAR Corrêa, MC Rodrigues and RF Mendes. Physical, mechanical and thermal behavior of adobe stabilized with glass fiber reinforced polymer waste. Constr. Build. Mater. 2019; 222, 168-82.

[40] F Wu, G Li, HN Li, JQ Jia. Strength and stress-strain characteristics of traditional adobe block and masonry. Mater.Struct. 2012; 46, 1449-57.

[41] I Kafodya, F Okonta and P Kloukinas. Role of fiber inclusion in adobe masonry construction. $J$. Build. Eng. 2019; 26, 100904.

[42] C Bock-Hyeng, AN Ofori-Boadu, E Yamb-Bell and MA Shofoluwe. Mechanical properties of sustainable adobe bricks stabilized with recycled sugarcane fiber waste. Int. J. Eng. Res. Appl. 2016; 6, 50-9.

[43] G Araya-Letelier, FC Antico, C Burbano-Garcia, J Concha-Riedel, J Norambuena-Contreras, J Concha and EIS Flores. Experimental evaluation of adobe mixtures reinforced with jute fibers. Constr. Build. Mater. 2021; 276, 122127.

[44] C Babé, DK Kidmo, A Tom, RRN Mvondo, RBE Boum and N Djongyang. Thermomechanical characterization and durability of adobes reinforced with millet waste fibers (sorghum bicolor). Case Stud. Constr. Mater. 2020; 13, e00422.

[45] E Olacia, AL Pisello, V Chiodo, S Maisano, A Frazzica and LF Cabeza. Sustainable adobe bricks with seagrass fibres. Mechanical and thermal properties characterization. Constr. Build. Mater. 2020; 239, 117669.

[46] G Araya-Letelier, H Gonzalez-Calderon, S Kunze, C Burbano-Garcia, U Reidel, C Sandoval and F Bas. Waste-based natural fiber reinforcement of adobe mixtures: Physical, mechanical, damage and durability performance assessment. 2020; 273, 122806.

[47] IMG Bertelsen, LJ Belmonte, G Fischer and LM Ottosen. Influence of synthetic waste fibres on drying shrinkage cracking and mechanical properties of adobe materials. Constr. Build. Mater. $2021 ; 286,122738$.

[48] K Dao, M Ouedraogo, Y Millogo, JE Aubert and M Gomina. Thermal, hydric and mechanical behaviours of adobes stabilized with cement. Constr. Build. Mater. 2018; 158, 84-96.

[49] P Zare, SS Narani, M Abbaspour, A Fahimifar, SMMMH Hosseini and P Zare. Experimental investigation of non-stabilized and cement-stabilized rammed earth reinforcement by Waste Tire Textile Fibers (WTTFs). Constr. Build. Mater. 2020; 260, 120432. 